\title{
Myoglobinuria and renal failure in toluene poisoning
}

\author{
E. REISIN, A. TEICHER, R. JAFFE, and H. E. ELIAHOU \\ Department of Nephrology and Internal Medicine, The Sheba Medical Center, \\ Tel-Hashomer, Israel
}

Toluene (methylbenzene) is a colourless liquid used as a solvent in the manufacture of synthetic rubber paint and lacquer as well as trinitrotoluene (Fairhall, 1957). Chronic or acute exposure to high concentrations is known to be toxic and to cause renal and hepatocellular damage (O'Brien, Yeoman, and Hobby, 1971). This report deals with severe myoglobinuria and acute renal failure necessitating haemodialysis after acute exposure to toluene.

\section{Case report}

A 49-year-old labourer in a paint factory was rushed to hospital after being found unconscious about 18 hours after a hose containing pure toluene had burst. He sustained superficial burns over the shoulder and arm (about $10 \%$ of the body surface area) from contact with toluene on the floor, and possibly aspirated toluene.

On admission to hospital there was clouding of consciousness, dyspnoea, and dehydration. The blood pressure was $130 / 80 \mathrm{mmHg}$, pulse 100 per minute, and body temperature $36.6^{\circ} \mathrm{C}$. Black urine was obtained on catheterization. A chest radiograph on admission showed a lower lobe pneumonic shadow on the left side. The haematocrit was $46 \%$, haemoglobin $15.6 \mathrm{~g} / \mathrm{dl}$, and leucocyte count 11300 with no eosinophils. Arterial blood pH was $7 \cdot 33, \mathrm{PCO}_{2} 4 \cdot 26 \mathrm{kPa}(32 \mathrm{mmHg}), \mathrm{PO}_{2} 12.0$ $\mathrm{kPa}(90 \mathrm{mmHg}), \mathrm{Hbo}_{2} 99.5 \%$, and bicarbonate 16.4 $\mathrm{mmol} / \mathrm{l}$. The blood urea was $7.6 \mathrm{mmol} / \mathrm{l}(46 \mathrm{mg} / 100 \mathrm{ml})$ and serum creatinine $371 \mu \mathrm{mol} / \mathrm{l}(4.2 \mathrm{mg} / 100 \mathrm{ml})$, giving a BUN/creatinine ratio of 5 . The serum potassium was $7.4 \mathrm{mmol} / \mathrm{l}$ but both sodium and chloride were normal. The urine gave a +++ ammonium sulphate test for myoglobin; no cells were present in the sediment. The urine osmolality was $293 \mathrm{mmol} / \mathrm{kg}$, and sodium 50 $\mathrm{mmol} / \mathrm{l}$, rising to $90 \mathrm{mmol} / 1$ the following day. Toluene was found in both blood and urine. Five days after admission he was found to have serum aspartate aminotransferase 90 units, creatine phosphokinase 53 units, lactic dehydrogenase 1196 units, and aldolase, 7.2 units. Treatment in the first instance consisted of intra- venous administration of $300 \mathrm{ml}$ per hour of glucose saline solution with $15 \mathrm{mEq}$ sodium bicarbonate Kayexalate, $15 \mathrm{~g}$ three times per day, was effective in reducing the hyperpotassaemia from 7.2 to $4.9 \mathrm{mmol} / 1$ within 12 hours. Initially, $250 \mathrm{ml}$ of $15 \%$ mannitol raised the urine output from $20 \mathrm{ml}$ to $140 \mathrm{ml}$ per hour. However, the next day frusemide was necessary to maintain a diuresis of 1.5 litres per day. In spite of the rapid correction of the acidosis, the high serum potassium, and the oliguria, the blood urea rose gradually from 7.6 to $28.9 \mathrm{mmol} / \mathrm{l}$ (46 to $174 \mathrm{mg} / 100 \mathrm{ml}$ ) in four days. The urine sodium ranged between 50 and $108 \mathrm{mmol} / \mathrm{l}$, urine potassium 10-24 $\mathrm{mmol} / \mathrm{l}$, urine urea concentration $83-95 \mathrm{mmol} / \mathrm{l}$ (500-570 $\mathrm{mg} / 100 \mathrm{ml}$ ), and urine osmolality $263-294 \mathrm{mmol} / \mathrm{kg}$, with a serum osmolality of $280-293 \mathrm{mmol} / \mathrm{kg}$. The diagnosis of non-oliguric acute renal failure due to myoglobinuria was made. Haemodialysis was instituted when the blood urea level reached $28.9 \mathrm{mmol} / 1(174 \mathrm{mg} / 100 \mathrm{ml})$ and the serum creatinine $548 \mu \mathrm{mol} / 1(6.2 \mathrm{mg} / 100 \mathrm{ml})$ and was performed on three occasions between the fifth and ninth hospital days.

The burns were treated topically with mafenide (Sulfamylon) cream applications. Ampicillin, $4 \mathrm{~g}$ per day, and prednisone, $50 \mathrm{mg}$ per day, were administered. By the tenth hospital day there was resolution of the lung shadow together with the onset of a moderate polyuria of 2-3 litres per day.

Two months later the blood urea was $5.6 \mathrm{mmol} / 1$ $(34 \mathrm{mg} / 100 \mathrm{ml})$, serum creatinine $79.6 \mu \mathrm{mol} / 1(0.9 \mathrm{mg} / 100$ $\mathrm{ml}$ ), and urine osmolality after a 12-hour withdrawal of fluids $510 \mathrm{mmol} / \mathrm{kg}$. Urinalysis was normal and urine culture was negative. Six months later he was found to have a blood urea of $6 \mathrm{mmol} / 1(36 \mathrm{mg} / 100 \mathrm{ml})$, serum creatinine $88.4 \mu \mathrm{mol} / 1(1.0 \mathrm{mg} / 100 \mathrm{ml})$, creatinine clearance $97 \mathrm{ml}$ per minute, and normal urinalysis.

\section{Discussion}

To our knowledge there is no publication documenting myoglobinuria with non-oliguric acute renal failure after acute toluene poisoning. The following 
sequence of events seems to have occurred: After the accidental spilling of the toluene in a closed space the patient inhaled sufficient amounts to cause loss of consciousness for the next 18 hours, and this is possibly the direct cause for the chemical pneumonitis which developed. The acute renal failure was possibly precipitated by the lack of fluid intake together with the heavy myoglobinuria.

Fever, chemical pneumonia, loss of consciousness, coma, conjunctivitis, headache, tachycardia, leucocytosis, and anaemia have been previously described following toluene poisoning (von Oettingen, 1958). A case of acute toluene intoxication with hyperbilirubinaemia and anuric acute renal failure suggesting hepatorenal syndrome has also been described (O'Brien et al., 1971). The combination of myoglobinuria and dehydration is known to produce acute renal failure in man (Muehrcke, 1969) and in the experimental animal (Thiel et al., 1967).

The low BUN/creatinine ratio described by Hamilton et al. (1972) in cases of myoglobinuria due to rhabdomyolysis was also noted in our patient, who had an initial ratio of about 5 . This ratio increased rather rapidly and was already about 13 just before his first haemodialysis on the fifth hospital day. This increase to the usual levels of over 10 (Dossetor, 1966) seems to indicate that the muscle damage was acute and transitory followed by acute tubular necrosis without further disproportionate creatininaemia.
It seems that the myoglobinuria was the direct cause of the renal failure which was rapidly transformed into a nonoliguric form by the early administration of intravenous fluids, osmotic diuretics, and frusemide. Recovery was complete.

\section{References}

Dossetor, J. B. (1966). Creatininemia versus uremia. The relative significance of blood urea nitrogen and serum creatinin concentrations in azotemia. Annals of Internal Medicine, 65, 1287-1299.

Fairhall, L. T. (1957). Industrial Toxicology, 2nd edition, p. 344. Williams and Wilkins, Baltimore.

Hamilton, R. W., Gardner, L. B., Penn, A. S., and Goldberg, M. (1972). Acute tubular necrosis caused by exercise-induced myoglobinuria. Annals of Internal Medicine, 77, 77-82.

Muehrcke, R. C. (1969). Acute Renal Failure: Diagnosis and Management, p. 198. C. V. Mosby, St. Louis.

O'Brien, E. T., Yeoman, W. B., and Hobby, J. A. E. (1971). Hepatorenal damage from toluene in a "glue sniffer". British Medical Journal, 2, 29-30.

Oettingen, W. F. von (1958). Poisoning, 2nd edition, p. 576. Saunders, Philadelphia.

Thiel, G., Wilson, D. R., Arce, M. L., and Oken, D. E. (1967). Glycerol induced hemoglobinuric acute renal failure in the rat. II. The experimental model, predisposing factors, and pathophysiologic features. Nephron, 4, 276-297.

Received for publication 24 April 1974.

Accepted for publication 19 September 1974.

\title{
Recent progress in the study of occupational lung diseases in Romania
}

\author{
B. BARHAD, L. PILAT, and D. TECULESCU \\ Institute of Hygiene and Public Health and Department of Industrial Medicine, Faculty \\ of Medicine, Bucharest, Romania
}

Barhad, B., Pilat, L., and Teculescu, D. (1975). British Journal of Industrial Medicine, 32, 164-168. Recent progress in the study of occupational lung diseases in Romania. This paper reviews studies of occupational lung diseases in Romania in the last two decades. Work concerned with the effects of exposure to textile fibres, irritant gases and fumes in the chemical industry, welding fumes, asbestos, cadmium oxide, and the relation between dust exposure, pneumoconiosis, and chronic bronchitis is briefly presented. 